\title{
Article \\ Perovskite Zinc Titanate Photocatalysts Synthesized by the Sol-Gel Method and Their Application in the Photocatalytic Degradation of Emerging Contaminants
}

\author{
Wei-Yu Chen ${ }^{1}$, Ching-Ping Wang ${ }^{2}$, Po-Chou Chen ${ }^{2}$, Kun-Yi Andrew Lin ${ }^{3}$, Surajit Ghosh ${ }^{4}$, \\ Chao-Wei Huang $2,5, *$ (D) and Van-Huy Nguyen $6, *$ (D)
}

Citation: Chen, W.-Y.; Wang, C.-P.; Chen, P.-C.; Lin, K.-Y.A.; Ghosh, S.; Huang, C.-W.; Nguyen, V.-H. Perovskite Zinc Titanate Photocatalysts Synthesized by the Sol-Gel Method and Their Application in the Photocatalytic Degradation of Emerging Contaminants. Catalysts 2021, 11, 854 https://doi.org/10.3390/ catal11070854

Academic Editor: Antonella Glisenti

Received: 1 July 2021

Accepted: 15 July 2021

Published: 16 July 2021

Publisher's Note: MDPI stays neutral with regard to jurisdictional claims in published maps and institutional affiliations.

Copyright: (c) 2021 by the authors. Licensee MDPI, Basel, Switzerland. This article is an open access article distributed under the terms and conditions of the Creative Commons Attribution (CC BY) license (https:// creativecommons.org/licenses/by/ $4.0 /)$
1 Department of Chemical and Materials Engineering, Southern Taiwan University of Science and Technology, Tainan 71005, Taiwan; weiyuchen@stust.edu.tw

2 Department of Chemical and Materials Engineering, National Kaohsiung University of Science and Technology, Kaohsiung 80778, Taiwan; owen07282013@gmail.com (C.-P.W.); a2386999@gmail.com (P.-C.C.)

3 i-Center for Advanced Science and Technology (iCAST), Innovation and Development Center of Sustainable Agriculture, Department of Environmental Engineering, National Chung Hsing University, Taichung 402227, Taiwan; linky@nchu.edu.tw

4 Department of Chemical Engineering, Malaviya National Institute of Technology, Jaipur 302017, India; surajit.chem@mnit.ac.in

5 Photo-SMART (Photo-Sensitive Material Advanced Research and Technology) Center, National Kaohsiung University of Science and Technology, Kaohsiung 80778, Taiwan

6 Faculty of Biotechnology, Binh Duong University, Thu Dau Mot 75000, Vietnam

* Correspondence: huangcw@nkust.edu.tw (C.-W.H.); nvhuy@bdu.edu.vn (V.-H.N.); Tel.: +886-(73)-814526 (ext. 15126) (C.-W.H.)

Abstract: In this study, perovskite $\mathrm{ZnTiO}_{3}$ photocatalysts were fabricated by the sol-gel method. The photocatalytic capability was verified by the degradation of the emerging contaminant, the antibiotic amoxicillin (AMX). For the preparation, the parameters of the calcination temperature and the additional amount of polyvinylpyrrolidone (PVP) and ammonia are discussed, including the calcining temperature $\left(500,600,700,800{ }^{\circ} \mathrm{C}\right)$, the volume of ammonia $(750,1500,3000 \mu \mathrm{L})$, and the weight of PVP ( $3 \mathrm{~g}$ and $5 \mathrm{~g}$ ). The prepared perovskite $\mathrm{ZnTiO}_{3}$ was characterized by XRD, FESEM, BET, and UV-Vis. It is shown that the perovskite $\mathrm{ZnTiO}_{3}$ photocatalysts are structurally rod-like and ultraviolet light-responsive. Consequently, the synthesis conditions for fabricating the perovskite $\mathrm{ZnTiO}_{3}$ photocatalysts with the highest photocatalytic performance were a calcining temperature of $700{ }^{\circ} \mathrm{C}$, an additional ammonia amount of $1500 \mu \mathrm{L}$, and added PVP of $5 \mathrm{~g}$. Moreover, the photocatalytic degradation of perovskite $\mathrm{ZnTiO}_{3}$ photocatalysts on other pollutants, including the antibiotic tetracycline (TC), methyl orange (MO), and methylene blue (MB) dyes, was also examined. This provides the basis for the application of perovskite $\mathrm{ZnTiO}_{3}$ as a photocatalyst to decompose emerging contaminants and organic pollutants in wastewater treatment.

Keywords: perovskite; $\mathrm{ZnTiO}_{3}$; photocatalyst; amoxicillin (AMX); tetracycline (TC); methyl orange (MO); methylene blue (MB)

\section{Introduction}

The use of antibiotics has increased with the development of medicine, fishery, and animal husbandry in recent years. In the aquatic environment, the sequencing proliferation of antibiotic-resistant genes (ARGs) and antibiotic-resistant bacteria (ARBs) has become a global issue. ARBs are transferred to drinking water sources via wastewater emissions in various circumstances, leading to a severe threat to human health, prolonging morbidity and increasing mortality. In fact, ARBs and ARGs have been discovered in various environments, such as aquaculture farms, hospital wastewater, livestock effluent wastewater, surface water, groundwater, wastewater treatment plants, etc. Even worse, ARGs and ARBs have been detected in untreated drinking water sources and even in tap or bottled water [1]. 
It was found that ARBs are generated due to ADP-ribosyl and glycosyltransferases with the sequential acetylation, phosphorylation, adenylation, nucleotidylation, ribosylation, and glycosylation of the antibiotics [2]. It was also reported that antibiotics cause the evolution of ARBs, even at low concentrations of the antibiotics [3]. Therefore, wastewater treatment to degrade antibiotics becomes more and more urgent.

Pharmaceutical antibiotics are also regarded as being among the emerging contaminants (ECs) [4]. Among the antibiotics, penicillins have played the most critical role in human and veterinary medicine [5]. In most countries, the consumption of penicillins accounts for $50-70 \%$ of the total amount of antibiotics [6]. Amoxicillin (AMX) is the most commonly used $\beta$-lactam antibiotic due to its broad action. It is often the first candidate for general infections [7]. While AMX is discharged into water resources through improper waste treatment methods, it could become a pollutant that would cause environmental damage. Accordingly, it is critical to develop a green procedure to decompose antibiotics and lower their emissions into natural water sources.

Various conventional and effective wastewater treatment technologies include coagulation, sedimentation, chlorination, flocculation, filtration, adsorption by activated carbon and carbon nanotubes, membrane filtration, ultraviolet radiation, ultrasonic treatment, and biological oxidation processes [8-11]. Compared with conventional technologies, advanced oxidation processes (AOPs) have also been developed to degrade antibiotics or convert them into smaller molecules. Consequently, the biodegradability and removal rate could be improved by conducting AOPs [12]. AOPs include ozonation [13], photocatalysis [14], the Fenton/photo-Fenton method [15], the Fenton-like method [16-18], electrochemical oxidation [19], ionizing radiation [20], etc. Among these, photocatalysis is regarded as a promising green technology to deal with wastewater due to its safety and cost effectiveness. Under suitable light irradiation, photocatalysts can generate electron-hole pairs, which form reactive oxygen species (ROSs), which can in turn decompose antibiotics effectively [21].

Photocatalytic degradation of antibiotics and organic pollutants has attracted more and more attention recently [4,22-28]. Many types of photocatalytic materials, such as multivariate metal-organic frameworks (MOFs) [29], bismuth subcarbonate $\left((\mathrm{BiO})_{2} \mathrm{CO}_{3}\right)$ [30], titanium dioxide $\left(\mathrm{TiO}_{2}\right)$ [31,32], iron oxide $\left(\mathrm{Fe}_{2} \mathrm{O}_{3}\right)$ [33,34], bismuth vanadate $\left(\mathrm{BiVO}_{4}\right)$ [35], and zinc oxide $(\mathrm{ZnO})[36,37]$, have been developed for photocatalysis. Regarding the decomposition of AMX, numerous photocatalysts have also been investigated. In 2010, Elmolla et al., pointed out that under UV light irradiation with a wavelength of $365 \mathrm{~nm}$, $\mathrm{ZnO}$ photocatalysts can decompose AMX by up to $59 \%, 72 \%$, and $100 \%$ under $\mathrm{pH}=5,8$, and 11 , respectively. This indicates that the $\mathrm{pH}$ value during synthesis has an influence on the performance of photocatalysis [36]. In 2012, Dimitrakopoulou et al., studied the photocatalysis of commercial $\mathrm{TiO}_{2}$ (P25) to degrade AMX under UVA light source irradiation, indicating that the initial concentration of the AMX solution also affects the performance of photocatalysts [31]. In 2014, Leong et al., fabricated $\mathrm{Ag} / \mathrm{TiO}_{2}$ photocatalysts to destroy the structure of AMX under visible light due to surface plasmon resonance (SPR) [38].

Composite materials are also regarded as excellent photocatalysts to degrade emerging contaminants due to the different synergistic effects of these binary materials. For example, Kanakaraju et al., integrated $\mathrm{TiO}_{2}$ / zeolite composites to remove AMX with light irradiation at a wavelength of $200 \sim 600 \mathrm{~nm}$ in 2015. AMX was successfully removed according to the mechanism of adsorption on zeolite and photocatalysis on $\mathrm{TiO}_{2}$ [39]. On the other hand, in 2016, Belaissa et al., indicated that $\mathrm{CuO}$ in the heterosystem of the $\mathrm{CuO} / \mathrm{TiO}_{2}$ photocatalyst acted as a sensitizer to absorb longer wavelength light through the synergistic effect. Accordingly, they effectively degraded AMX by using simulated sunlight illumination [40]. In contrast, Yang et al., fabricated a novel composite photocatalyst that was constructed from a MOF, MIL-68(In)- $\mathrm{NH}_{2}$, and graphene oxide (GrO). Based on the semiconductor properties of MOFs and the excellent electron transport performance of $\mathrm{GrO}$, the composite materials exhibited an excellent photocatalytic activity under illumination by a light source with a wavelength of $420 \mathrm{~nm}$. The experimental results showed that MIL-68(In)- $\mathrm{NH}_{2} / \mathrm{GrO}$ 
had better performance in decomposing AMX than the individual materials alone [41]. Graphite carbon nitride $\left(\mathrm{g}-\mathrm{C}_{3} \mathrm{~N}_{4}\right)$ is also a promising candidate for photocatalysis due to its excellent chemical stability, unique two-dimensional structure, and small energy gap $(2.70 \mathrm{eV})$. Dou et al., utilized g- $\mathrm{C}_{3} \mathrm{~N}_{4}$ to successfully degrade AMX at different initial concentrations in 2019 [42]. Similarly, in 2019, Mirzaei et al., prepared $\mathrm{Fe}_{3} \mathrm{O}_{4} / \mathrm{g}-\mathrm{C}_{3} \mathrm{~N}_{4}$ photocatalysts irradiated under different light sources to decompose AMX in a solution [43].

To the best of our knowledge, there have been few perovskite materials used in the degradation of AMX. In 2018, Haddadou et al., indicated that perovskite $\mathrm{Ba}\left(\mathrm{Ti}_{0.950} \mathrm{Sc}_{0.025}\right.$ $\left.\mathrm{Nb}_{0.025}\right) \mathrm{O}_{3}$ photocatalysts showed a large dielectric constant and a wide space charge region, which were helpful in the photocatalytic degradation of AMX [44]. Kong et al., synthesized and characterized perovskite $\mathrm{ZnTiO}_{3}$ photocatalysts. The photocatalytic performance of the azo dye methyl violet was also verified [45]. Therefore, based on the above discussion, perovskite $\mathrm{ZnTiO}_{3}$ could serve as a potential photocatalyst to decompose emerging contaminants. In fact, perovskite $\mathrm{ZnTiO}_{3}$ is also used in a wide array of applications, such as on gas sensors, microwave dielectrics, and sorbents; therefore, it is critical to develop a facile method to fabricate $\mathrm{ZnTiO}_{3}$. In this study, $\mathrm{AMX}$ is the targeted molecule, and various perovskite $\mathrm{ZnTiO}_{3}$ photocatalysts were prepared using a simple sol-gel method under various synthesis conditions to verify their photocatalytic performance.

\section{Results}

The uncalcinated $\mathrm{ZnTiO}_{3}$ photocatalysts were submitted to thermogravimetric analysis and differential thermal analysis, as shown in Figure 1. Initially, a weight loss of 19.9\% was observed before $200{ }^{\circ} \mathrm{C}$ in the first stage, mainly due to the evaporation of the glycol solvent [46]. A weight loss of $40.5 \%$ occurred from 200 to $500{ }^{\circ} \mathrm{C}$ in the second stage. In the second stage as well, thermal decomposition with a maximum weight loss of $31.4 \%$ was observed at $315^{\circ} \mathrm{C}$. This indicated that massive thermal cracking of PVP and dehydroxylation of $\mathrm{Ti}-\mathrm{OH}$ to $\mathrm{TiO}_{2}$ occurred in this stage. The sharp peak that appeared at $315.5^{\circ} \mathrm{C}$ was attributed to the combustion of organic compounds [47]. The weight loss in the third stage between 500 and $800{ }^{\circ} \mathrm{C}$ reached $42.4 \%$, and the weight loss increased by approximately $2 \%$, indicating that the residual organic components had been burned out. Since the TGA curve did not change much after $500{ }^{\circ} \mathrm{C}$, this suggested that the samples had to be calcined above this temperature at least to remove the organic precursors. Accordingly, the thermal post-treatments of the as-prepared $\mathrm{ZnTiO}_{3}$ samples were set at 500, 600, 700, and $800{ }^{\circ} \mathrm{C}$.

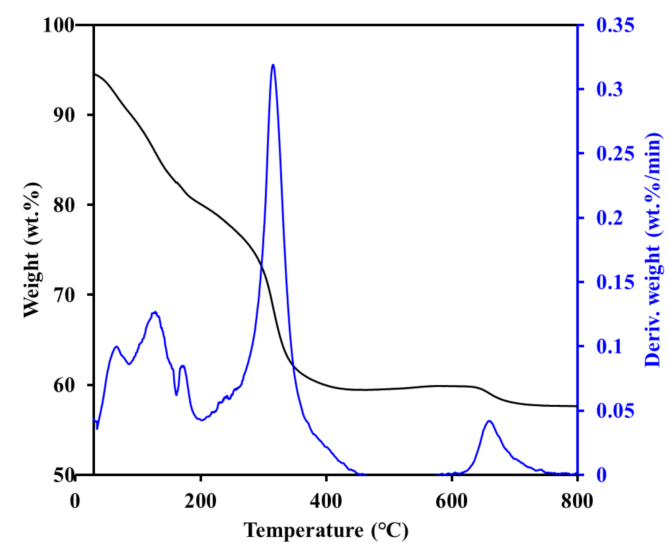

Figure 1. Thermogravimetric analysis and differential thermal analysis of the uncalcinated $\mathrm{ZnTiO}_{3}$ photocatalysts.

The XRD patterns of the $\mathrm{ZnTiO}_{3}$ photocatalysts at various calcination temperatures are shown in Figure 2. For the case of $500{ }^{\circ} \mathrm{C}$, the signal of the XRD pattern was not sharp. These weak and broad peaks, such as $30.1^{\circ}(220), 35.2^{\circ}(311), 42.4^{\circ}(400), 53.3^{\circ}(422), 56.9^{\circ}$ (511), and 61.8 (440), indicated the existence of cubic $\mathrm{Zn}_{2} \mathrm{TiO}_{4}$ (JCPDS 25-1164). This also means that the calcination temperature of $500{ }^{\circ} \mathrm{C}$ was not enough for the crystallization of 
$\mathrm{ZnTiO}_{3}$. As the calcination temperature reached $600^{\circ} \mathrm{C}$, several peaks including $14.9^{\circ}(110)$, $23.6^{\circ}(210), 26.0^{\circ}(211), 30.0^{\circ}(220), 35.3^{\circ}(311), 43.0^{\circ}(400), 53.3^{\circ}(422), 56.9^{\circ}(511)$, and $62.4^{\circ}$ (440) were observed, representing the formation of cubic-phase $\mathrm{ZnTiO}_{3}$ (JCPDS 39-0190). The strength of these peaks increased even more rapidly at $700{ }^{\circ} \mathrm{C}$. As the temperature of heat treatment increased further, the cubic phase of $\mathrm{ZnTiO}_{3}$ was transformed into the hexagonal phase at $800{ }^{\circ} \mathrm{C}$ [48]. The characterized hexagonal phase was verified from the $2 \theta$ of $19.15^{\circ}(003), 23.9^{\circ}(012), 32.7^{\circ}(104), 35.3^{\circ}(110), 38.8^{\circ}(006), 40.5^{\circ}(113), 50.3^{\circ}$ (107), 53.4 (116), 56.8 (018), and 61.8 (214) (JCPDS 26-1500). On the other hand, the XRD pattern also revealed that the cubic-phase $\mathrm{ZnTiO}_{3}$ was partially decomposed into cubic $\mathrm{Zn}_{2} \mathrm{TiO}_{4}$ at $800{ }^{\circ} \mathrm{C}$. Accordingly, the different calcination temperatures had a significant impact on the crystallinity of $\mathrm{ZnTiO}_{3}$.

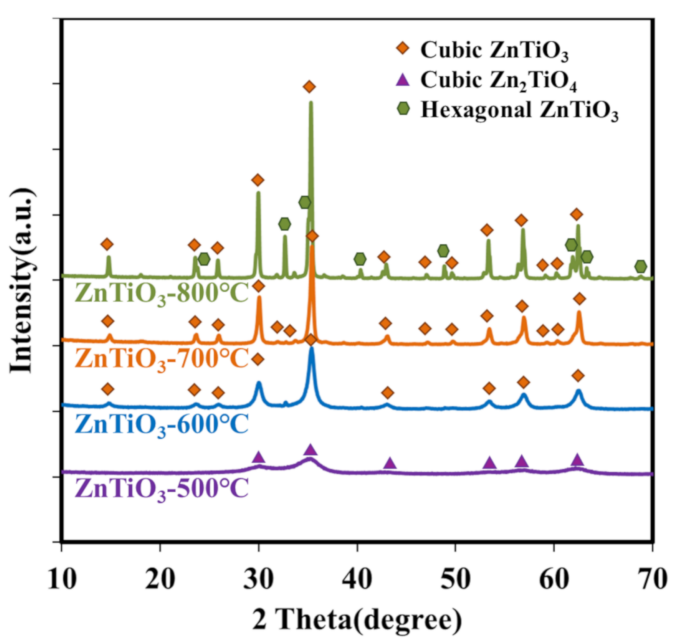

Figure 2. The XRD patterns of $\mathrm{ZnTiO}_{3}$ photocatalysts (prepared by adding $1500 \mu \mathrm{L} \mathrm{NH}_{4} \mathrm{OH}$ and $5 \mathrm{~g}$ PVP) at various calcination temperatures from $500 \sim 800^{\circ} \mathrm{C}$.

The effect of various additional $\mathrm{NH}_{4} \mathrm{OH}$ amounts during synthesis on the crystallinity is shown in Supplementary Materials Figure S1. The crystallinities of $\mathrm{ZnTiO}_{3}$ prepared by adding $750 \mu \mathrm{L}$ and $1500 \mu \mathrm{L}$ of $\mathrm{NH}_{4} \mathrm{OH}$ during the synthesis seem very similar, indicating mainly cubic $\mathrm{ZnTiO}_{3}$ (JCPDS 39-0190. When the amount of $\mathrm{NH}_{4} \mathrm{OH}$ was increased to $3000 \mu \mathrm{L}$, a small amount of cubic $\mathrm{Zn}_{2} \mathrm{TiO}_{4}$ crystal (JCPDS 25-1164) appeared. On the other hand, the effect of adding PVP on the crystallinity was also examined. When the amount of PVP of $3 \mathrm{~g}$ was added, primarily cubic $\mathrm{ZnTiO}_{3}$ appeared along with some cubic $\mathrm{Zn}_{2} \mathrm{TiO}_{4}$. However, increasing the amount of PVP up to $7 \mathrm{~g}$ resulted in the viscosity of the solution being too high to obtain a homogeneous solution; therefore, Figure $\mathrm{S} 2$ only reveals the XRD patterns of the cases of $3 \mathrm{~g}$ and $5 \mathrm{~g}$ of PVP.

In Figure 3, the FTIR spectra of various $\mathrm{ZnTiO}_{3}$ calcinated at 500, 600, 700, and $800{ }^{\circ} \mathrm{C}$ are shown. The absorption peak within the lower wavenumber region $\left(480 \sim 750 \mathrm{~cm}^{-1}\right)$ was mainly attributed to the Ti-O vibration. $\mathrm{Zn}-\mathrm{O}-\mathrm{Ti}$ groups were also observed at $735 \mathrm{~cm}^{-1}$ [49]. This suggested that crystalline $\mathrm{ZnTiO}_{3}$ was formed when the calcination temperature was higher than $600{ }^{\circ} \mathrm{C}$, which agreed well with the XRD results. Meanwhile, a broad peak near $3400 \mathrm{~cm}^{-1}$ was attributed to free water or adsorbed water, which was related to the $\mathrm{OH}$ stretching. There were several peaks between 845 and $1496 \mathrm{~cm}^{-1}$, which indicated the existence of PVP residues [50]. Meanwhile, the absorption peak near $1620 \sim 1630 \mathrm{~cm}^{-1}$ belonged to the bending vibrations of Ti-OH [51,52], suggesting that $\mathrm{ZnTiO}_{3}$ is hydrophilic. The peak intensities of the $\mathrm{OH}$ stretching and PVP residues gradually decreased with increasing calcination temperature, which indicated that the water content and PVP residues decreased with the increase in the calcination temperature. Subsequently, the effect of $\mathrm{NH}_{4} \mathrm{OH}$ and PVP addition on the FTIR spectra was also examined; however, the difference of the spectra was not significant, and no obvious signals of water or Ti-OH were observed, but Ti-O was, as shown in Figure S3. 


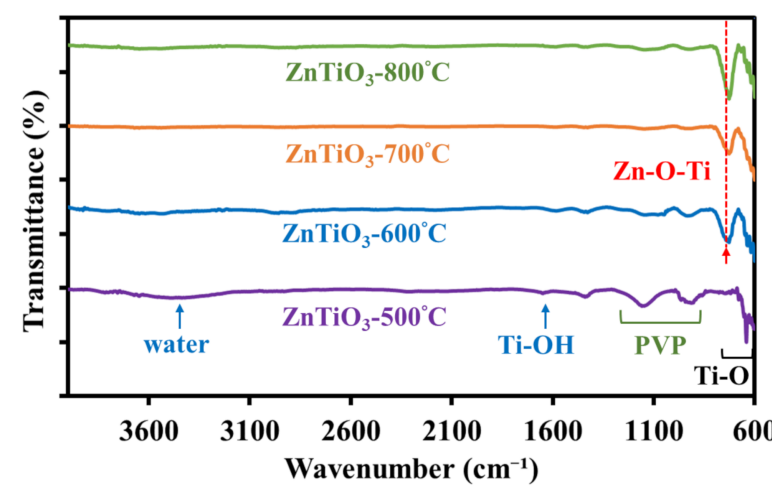

Figure 3. FTIR spectra of various $\mathrm{ZnTiO}_{3}$ calcinated at $500 \sim 800{ }^{\circ} \mathrm{C}$.

The SEM images of $\mathrm{ZnTiO}_{3}-500{ }^{\circ} \mathrm{C}, \mathrm{ZnTiO}_{3}-600{ }^{\circ} \mathrm{C}, \mathrm{ZnTiO}_{3}-700{ }^{\circ} \mathrm{C}$, and $\mathrm{ZnTiO}_{3}-$ $800{ }^{\circ} \mathrm{C}$ are shown in Figures $4 \mathrm{a}-\mathrm{d}$ and $4 \mathrm{e}-\mathrm{h}$ at magnifications of $10,000 \times$ and $30,000 \times$, respectively. In Figure $4 \mathrm{a}-\mathrm{d}$, most of the $\mathrm{ZnTiO}_{3}$ has a sharp rod shape. The one-dimensional morphology could be mainly attributed to the limitation of PVP during synthesis [53]. PVP could assemble concurrently on the surface of $\mathrm{ZnTiO}_{3}$, preventing $\mathrm{ZnTiO}_{3}$ from growing along the radial direction of the rod. After calcination, PVP would be burned out, and mesoporous $\mathrm{ZnTiO}_{3}$ rods could be formed. The size and length of the $\mathrm{ZnTiO}_{3}$ rods were approximately $0.5 \sim 0.8 \mu \mathrm{m}$ and $1 \sim 4 \mu \mathrm{m}$, respectively. As a demonstration, in Figure $4 \mathrm{e}-\mathrm{h}$, the cross-sectional shapes of the $\mathrm{ZnTiO}_{3}$ rods are irregular or hexagonal. At a magnification of $30,000 \times$, it is clearly observed that the surfaces of the $\mathrm{ZnTiO}_{3}-500{ }^{\circ} \mathrm{C}$ and $\mathrm{ZnTiO}_{3}-600{ }^{\circ} \mathrm{C}$ rods are relatively smooth and distinct. On the contrary, the surfaces of the $\mathrm{ZnTiO}_{3}-700{ }^{\circ} \mathrm{C}$ and $\mathrm{ZnTiO}_{3}-800{ }^{\circ} \mathrm{C}$ rods are relatively rough and thick, with some connections between the rods. Accordingly, we speculated that the increase in the calcination temperature caused smaller particles to be sintered together into larger particles due to the thermal migration [54].
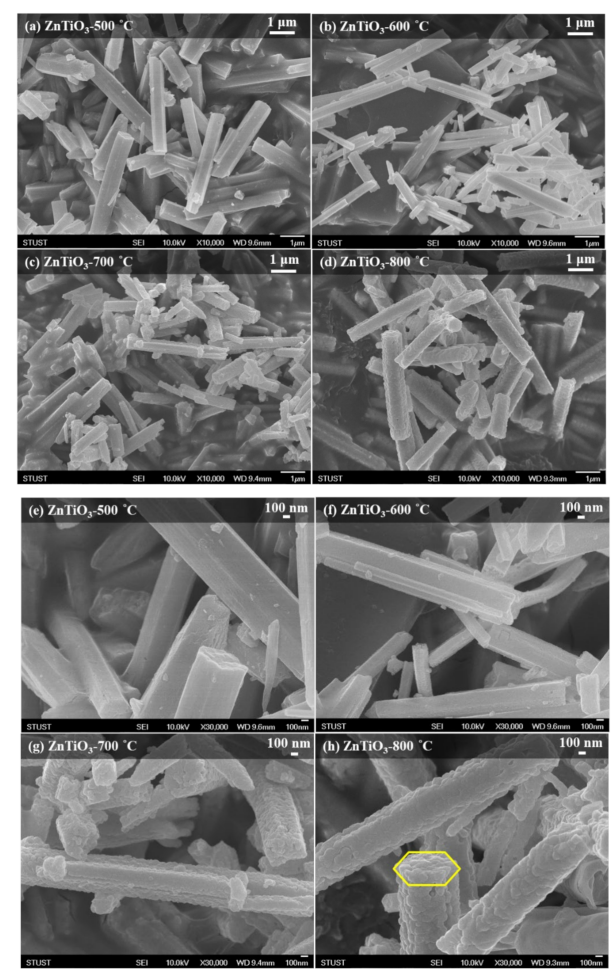

Figure 4. (a-d) $\mathrm{SEM}$ images of $\mathrm{ZnTiO}_{3}-500{ }^{\circ} \mathrm{C}, \mathrm{ZnTiO}_{3}-600{ }^{\circ} \mathrm{C}, \mathrm{ZnTiO}_{3}-700{ }^{\circ} \mathrm{C}$, and $\mathrm{ZnTiO}_{3}-800{ }^{\circ} \mathrm{C}$ at a magnification of $10,000 \times$. (e-h) $\mathrm{SEM}$ images of $\mathrm{ZnTiO}_{3}-500{ }^{\circ} \mathrm{C}, \mathrm{ZnTiO}_{3}-600{ }^{\circ} \mathrm{C}, \mathrm{ZnTiO}_{3}-700{ }^{\circ} \mathrm{C}$, and $\mathrm{ZnTiO}_{3}-800{ }^{\circ} \mathrm{C}$ at a magnification of $30,000 \times$. 
With the increase of the amount of $\mathrm{NH}_{4} \mathrm{OH}$, the length of the rod-shaped $\mathrm{ZnTiO}_{3}$ increased. As shown in Figure S4, the length of the $\mathrm{ZnTiO}_{3}-\mathrm{N} 750$ rods is shorter than those of $\mathrm{ZnTiO}_{3}-\mathrm{N} 1500$ and $\mathrm{ZnTiO}_{3}-\mathrm{N} 3000$. Some of the $\mathrm{ZnTiO}_{3}-\mathrm{N} 750$ had not yet formed a rod shape. When the amount of $\mathrm{NH}_{4} \mathrm{OH}$ reached $1500 \mu \mathrm{L}$, most of the obtained $\mathrm{ZnTiO}_{3}-\mathrm{N} 1500$ maintained a rod shape with a length of around $1 \sim 4 \mu \mathrm{m}$. Compared with $\mathrm{ZnTiO}_{3}-\mathrm{N} 1500$, $\mathrm{ZnTiO}_{3}-\mathrm{N}_{3000}$ revealed rod shapes with longer lengths and a thicker size. The lengths of some $\mathrm{ZnTiO}_{3}-\mathrm{N} 3000$ could even exceed $9 \mu \mathrm{m}$. The possible reason was the increase in the amount of $\mathrm{NH}_{4} \mathrm{OH}$, which would accelerate $\mathrm{ZnTiO}_{3}$ formation in a short time during the synthesis. Such a greater amount of $\mathrm{ZnTiO}_{3}$ caused continual growth simultaneously along the axial and radial directions despite the presence of PVP as the template. Moreover, the influence of the different additional amounts of PVP on the morphology was not apparent. In Figure $\mathrm{S} 5, \mathrm{ZnTiO}_{3}-\mathrm{P} 3$ only shows a slightly smaller cross-sectional length and width compared to $\mathrm{ZnTiO}_{3}-\mathrm{P} 5$. Generally, the concentration of PVP had a critical impact on the morphology due to the formation of micelles with different morphologies. There was a tendency for the aspect ratio of the crystals to became larger with the increase in the concentration of the PVP in the solution [55]. Besides, a higher PVP concentration might result in a more viscous solution, which could cause the instability of the nanofibers and generate more irregular structures [56]. This also proved that less PVP addition to the $\mathrm{ZnTiO}_{3}-\mathrm{P} 3$ resulted in less agglomeration or bead formation than the case of $\mathrm{ZnTiO}_{3}-\mathrm{P} 5$.

The information of the particle sizes observed from the SEM and element analysis results obtained by EDS is shown in Table $1 . \mathrm{ZnTiO}_{3}$ photocatalysts calcinated at different temperatures resulted in the detection of $\mathrm{O}, \mathrm{Zn}$, and $\mathrm{Ti}$, which proved the formation of $\mathrm{ZnTiO}_{3}$. Moreover, the $\mathrm{Zn} / \mathrm{Ti}$ atomic ratios of $\mathrm{ZnTiO}_{3}-600{ }^{\circ} \mathrm{C}$ and $\mathrm{ZnTiO}_{3}-700^{\circ} \mathrm{C}$ were close to 1:1, which was consistent with the main composition of $\mathrm{ZnTiO}_{3}$ detected by XRD [53]. In comparison, the $\mathrm{Zn} / \mathrm{Ti}$ atomic ratios of $\mathrm{ZnTiO}_{3}-800{ }^{\circ} \mathrm{C}$ were close to $4: 3$, which might be derived from the multiple crystalline phases proven by XRD. On the other hand, the effects of $\mathrm{NH}_{4} \mathrm{OH}$ and $\mathrm{PVP}$ on the composition ratio were not noticeable, while the calcination temperature was fixed at $700{ }^{\circ} \mathrm{C}$. Accordingly, the $\mathrm{Zn} / \mathrm{Ti}$ atomic ratios of $\mathrm{ZnTiO}_{3}$ samples were still close to 1:1.

Table 1. The particle size and element analysis of $\mathrm{ZnTiO}_{3}$ prepared in various conditions.

\begin{tabular}{|c|c|c|c|c|c|c|c|}
\hline & $\begin{array}{c}\mathrm{ZnTiO}_{3}- \\
500^{\circ} \mathrm{C}\end{array}$ & $\begin{array}{c}\mathrm{ZnTiO}_{3-} \\
600^{\circ} \mathrm{C}\end{array}$ & $\begin{array}{c}\mathrm{ZnTiO}_{3-} \\
700^{\circ} \mathrm{C}- \\
\mathrm{N} 1500-\mathrm{P} 5\end{array}$ & $\begin{array}{c}\mathrm{ZnTiO}_{3}- \\
800^{\circ} \mathrm{C}\end{array}$ & $\begin{array}{c}\mathrm{ZnTiO}_{3}- \\
\mathrm{N750}\end{array}$ & $\begin{array}{c}\mathrm{ZnTiO}_{3}- \\
\text { N3000 }\end{array}$ & $\mathrm{ZnTiO}_{3}-\mathrm{P3}$ \\
\hline Element & & & & Atomic \% & & & \\
\hline $\mathrm{O}$ & 75.02 & 76.37 & 77.27 & 14.60 & 65.92 & 78.81 & 75.58 \\
\hline $\mathrm{Zn}$ & 12.34 & 11.59 & 11.11 & 48.74 & 15.25 & 10.93 & 11.65 \\
\hline $\mathrm{Ti}$ & 12.64 & 12.04 & 11.62 & 36.66 & 18.83 & 10.26 & 12.77 \\
\hline Dimension & \multicolumn{7}{|c|}{ Particle size $(\mu \mathrm{m})$} \\
\hline length & \multicolumn{4}{|c|}{$1 \sim 4$} & $1 \sim 3$ & $3 \sim 6$ & $1 \sim 2$ \\
\hline size & \multicolumn{4}{|c|}{$0.5 \sim 0.8$} & $0.5 \sim 0.8$ & $0.8 \sim 1.2$ & $\sim 0.5$ \\
\hline
\end{tabular}

To determine the specific surface area and pore properties of the prepared $\mathrm{ZnTiO}_{3}$ photocatalysts, $\mathrm{N}_{2}$ adsorption-desorption analysis was carried out. In Figure $5 \mathrm{a}$, the $\mathrm{N}_{2}$ adsorption-desorption isotherms of all $\mathrm{ZnTiO}_{3}$ photocatalysts are confirmed as type IV isotherms. As the calcinating temperature increased, the hysteresis loop gradually right-shifted to a higher relative pressure. Besides, the closed area of the hysteresis loop became narrower with the increase in the calcination temperature [57]. Figure $5 \mathrm{~b}$ reveals the pore size distribution of the $\mathrm{ZnTiO}_{3}$ photocatalysts as mainly from 2 to $50 \mathrm{~nm}$, owing to their mesoporous properties. It is interesting to note that the addition of $\mathrm{NH}_{4} \mathrm{OH}$ and PVP did not affect the pore structure and specific surface area. The variance of the $\mathrm{N}_{2}$ adsorption-desorption isotherms among the different $\mathrm{ZnTiO}_{3}$ photocatalysts prepared with different amounts of $\mathrm{NH}_{4} \mathrm{OH}$ and PVP was not significant, as shown in Figure S6. 
This suggested that the additional amounts of $\mathrm{NH}_{4} \mathrm{OH}$ and PVP might be saturated, so that the pore structures of the samples would not be affected. Table 2 brings together all the $\mathrm{ZnTiO}_{3}$ samples. It can be observed that as the calcining temperature increased, the specific surface area value dropped sharply. The main reason was the shrinkage of the air gaps between the particles and the agglomeration of $\mathrm{ZnTiO}_{3}$ during sintering [58].
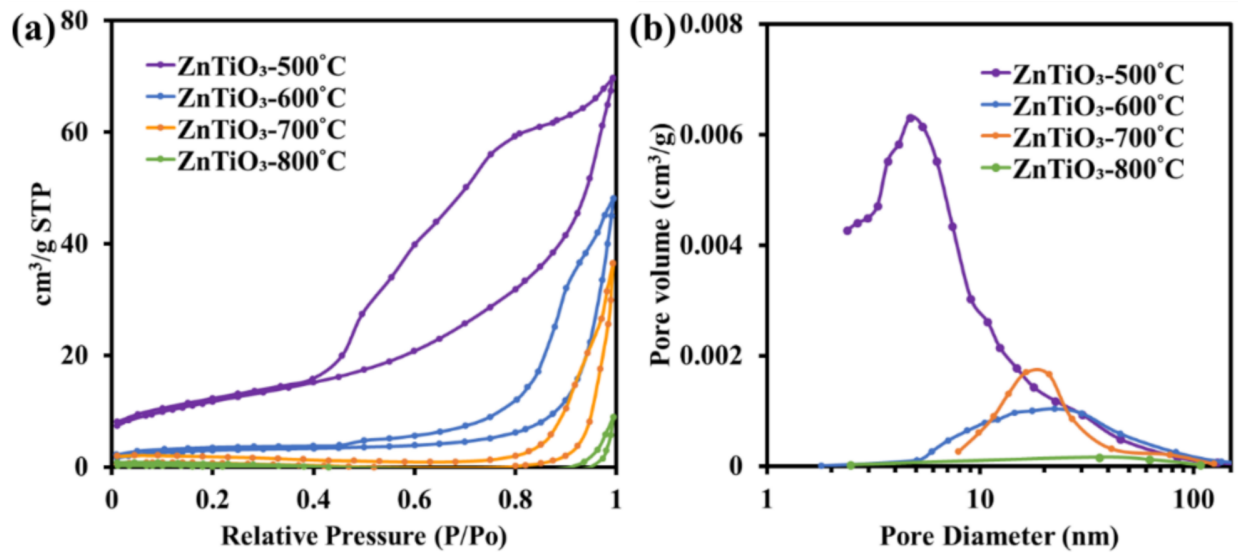

Figure 5. (a) The $\mathrm{N}_{2}$ adsorption-desorption isotherms and (b) the pore size distribution of $\mathrm{ZnTiO}_{3}$ prepared at $500 \sim 800{ }^{\circ} \mathrm{C}$.

Table 2. BET specific surface area of $\mathrm{ZnTiO}_{3}$ prepared in various conditions.

\begin{tabular}{cccccccc}
\hline $\begin{array}{c}\text { Specific } \\
\text { Surface Area }\end{array}$ & $\mathrm{ZnTiO}_{3}-500{ }^{\circ} \mathrm{C}$ & $\mathrm{ZnTiO}_{3}-600{ }^{\circ} \mathrm{C}$ & $\begin{array}{c}\mathrm{ZnTiO}_{3}-\mathbf{7 0 0} \\
{ }^{\circ} \mathrm{C}-\mathrm{N1500-P5}\end{array}$ & $\mathrm{ZnTiO}_{3}-\mathbf{8 0 0}{ }^{\circ} \mathrm{C}$ & $\begin{array}{c}\mathrm{ZnTiO}_{3^{-}} \\
\mathrm{N750}^{-}\end{array}$ & $\begin{array}{c}\mathrm{ZnTiO}_{3^{-}} \\
\mathrm{N3000}^{-}\end{array}$ & $\begin{array}{c}\mathrm{ZnTiO}_{3^{-}} \\
\mathbf{P 3}^{-}\end{array}$ \\
\hline $\mathrm{BET}\left(\mathrm{m}^{2} / \mathrm{g}\right)$ & 42.0 & 10.0 & 6.7 & 0.2 & 6.0 & 5.4 & 6.1 \\
\hline
\end{tabular}

The UV-Vis analysis of the $\mathrm{ZnTiO}_{3}$ photocatalysts is illustrated in Figure $6 . \mathrm{ZnTiO}_{3}$ $500{ }^{\circ} \mathrm{C}, \mathrm{ZnTiO}_{3}-600{ }^{\circ} \mathrm{C}, \mathrm{ZnTiO}_{3}-700{ }^{\circ} \mathrm{C}$, and $\mathrm{ZnTiO}_{3}-800{ }^{\circ} \mathrm{C}$ had their maximum absorption at the wavelengths of $300 \mathrm{~nm}, 286 \mathrm{~nm}, 286 \mathrm{~nm}$, and $290 \mathrm{~nm}$, respectively. This indicated that as the calcination temperatures increased, the UV-Vis absorption exposed a blue shift toward shorter wavelengths. By plotting the Tauc curve of (Ahv $)^{2}$ vs. hv [59], the bandgaps of the $\mathrm{ZnTiO}_{3}$ photocatalysts were obtained as shown in the embedded graph of Figure 6, where $\mathrm{A}$ is the light absorbance and hv is the energy of a photon. Hence, the energy gaps of $\mathrm{ZnTiO}_{3}-500{ }^{\circ} \mathrm{C}, \mathrm{ZnTiO}_{3}-600{ }^{\circ} \mathrm{C}, \mathrm{ZnTiO}_{3}-700{ }^{\circ} \mathrm{C}$, and $\mathrm{ZnTiO}_{3}-800{ }^{\circ} \mathrm{C}$ were $3.54,3.63,3.72$, and $3.75 \mathrm{eV}$, respectively. This indicated that the increasing calcination temperature led to increasing grain size; therefore, the band-gaps of $\mathrm{ZnTiO}_{3}$ became large due to the quantum effect [60]. Meanwhile, the effects of $\mathrm{NH}_{4} \mathrm{OH}$ or PVP addition were not significant, as shown in Figure S7. The band-gaps of $\mathrm{ZnTiO}_{3}$ with different $\mathrm{NH}_{4} \mathrm{OH}$ and PVP modifications were around $3.72 \mathrm{eV}$.

AMX degradation on $\mathrm{ZnTiO}_{3}$ was implemented in two steps, dark adsorption and photocatalysis. Thus, Figure $7 \mathrm{a}, \mathrm{b}$ expresses the concentration ratios of $\mathrm{C} / \mathrm{C}_{0}$ and $\mathrm{C} / \mathrm{C}_{\mathrm{L} 0}$, which indicate the performance of dark adsorption and photocatalysis, respectively. Before the LEDs were turned on, the AMX concentration was decreased due to the dark adsorption of $\mathrm{AMX}$ by the various $\mathrm{ZnTiO}_{3}$. In Figure $7 \mathrm{a}, \mathrm{ZnTiO}_{3}-500{ }^{\circ} \mathrm{C}$ could diminish the $\mathrm{AMX}$ by $20 \%$. This might be attributed to the excellent specific surface area of $\mathrm{ZnTiO}_{3}-500{ }^{\circ} \mathrm{C}$ compared to that of the other photocatalysts. After 50 min of dark adsorption, the adsorption reached an equilibrium, and the LEDs were turned on to conduct the photocatalytic reaction for $180 \mathrm{~min}$. After light irradiation, the AMX concentration decreased with the irradiation time. Figure $7 \mathrm{~b}$ reveals the photocatalytic degradation ratios to be about 47.9, 53.3, 63.8, and $45.4 \%$ for $\mathrm{ZnTiO}_{3}-500{ }^{\circ} \mathrm{C}, \mathrm{ZnTiO}_{3}-600{ }^{\circ} \mathrm{C}, \mathrm{ZnTiO}_{3}-700{ }^{\circ} \mathrm{C}$, and $\mathrm{ZnTiO}_{3}-800{ }^{\circ} \mathrm{C}$, respectively. 


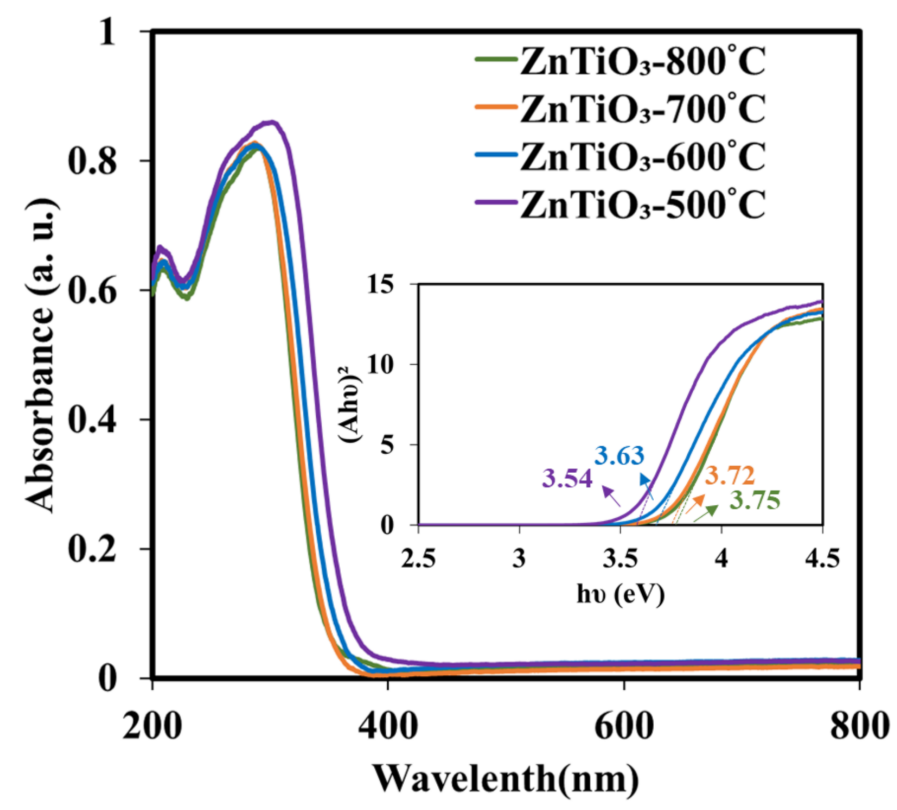

Figure 6. UV-Vis results of $\mathrm{ZnTiO}_{3}$ calcinated at $500 \sim 800{ }^{\circ} \mathrm{C}$.
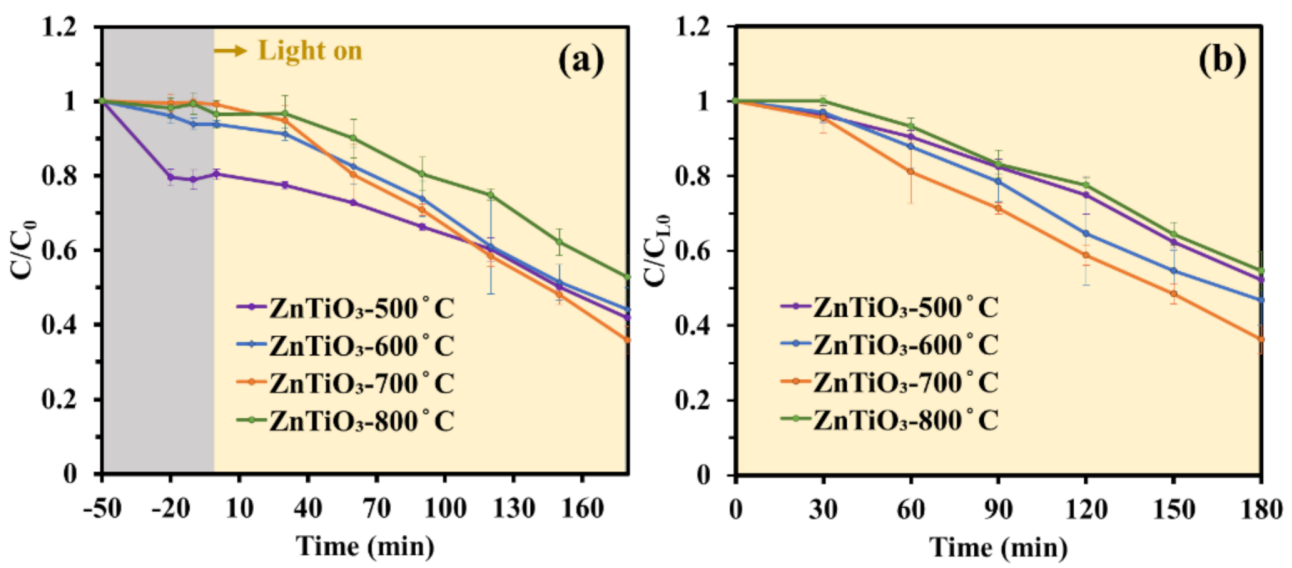

Figure 7. The changes of (a) $\mathrm{C} / \mathrm{C}_{0}$ and (b) $\mathrm{C} / \mathrm{C}_{\mathrm{L} 0}$ for various $\mathrm{ZnTiO}_{3}$ calcinated $\mathrm{t} 500 \sim 800{ }^{\circ} \mathrm{C}$ with the reaction time to degrade $\mathrm{AMX}$.

Although $\mathrm{ZnTiO}_{3}-500{ }^{\circ} \mathrm{C}$ had the smallest band-gap and the highest specific surface area, its photocatalytic performance was not the best, which might be related to the poor crystalline form revealed by XRD. While the calcination temperature reached $600 \sim 700{ }^{\circ} \mathrm{C}$, the cubic $\mathrm{ZnTiO}_{3}$ became the dominant crystalline phase and showed a good photocatalytic activity. Moreover, $\mathrm{ZnTiO}_{3}-700^{\circ} \mathrm{C}$ showed better crystallinity in the cubic phase compared to $\mathrm{ZnTiO}_{3}-600{ }^{\circ} \mathrm{C}$, resulting in better photocatalytic performance. $\mathrm{ZnTiO}_{3}-800{ }^{\circ} \mathrm{C}$ appeared as hexagonal $\mathrm{ZnTiO}_{3}$, leading to a decrease in photocatalytic performance, despite another study advocating that hexagonal $\mathrm{ZnTiO}_{3}$ exhibited the strongest photocatalytic performance [45]. The poor photocatalytic performance of $\mathrm{ZnTiO}_{3}-800{ }^{\circ} \mathrm{C}$ might be attributed to its extremely low specific surface area, which would lower the possibility of surface adsorption and reaction. Unfortunately, the tuning of various additional amounts of $\mathrm{NH}_{4} \mathrm{OH}$ and PVP would not affect the photocatalytic performance of AMX degradation, as shown in Figure S8a,b, respectively. Their similar performance might be due to their similar specific surface area and degree of crystallinity. Therefore, we could conclude that the crystallinity and specific surface area of $\mathrm{ZnTiO}_{3}$ are the primary factors affecting the photocatalytic performance in the degradation of AMX. Supplementary Materials Table S1 provides a comparison of the activities of different photocatalysts in the degradation of AMX with the 
supporting data. This suggested that $\mathrm{ZnTiO}_{3}-700{ }^{\circ} \mathrm{C}$ is a simple photocatalysts with the potential to degrade AMX under low-intensity UV light irradiation.

The possible photocatalysis mechanism is shown in Figure 8. After light irradiation, light-excited electrons and holes would react with $\mathrm{O}_{2}$ and $\mathrm{OH}^{-}$to form $\cdot \mathrm{O}_{2}{ }^{-}$and $\mathrm{OH}$ radicals to attack the $\beta$-lactam ring of AMX, followed by the concentration degradation, which could be observed by the absorbance of the AMX solution. Moreover, the photocatalytic degradation of AMX using P25 was conducted to serve as a standard case. Following a similar photocatalytic process, the AMX concentration slightly increased for the case of P25 during dark adsorption, as shown in Figure S9. This might result from the incomplete separation of AMX and P25, in which the absorption peaks, AMX: $227.5 \mathrm{~nm}$ and P25: $<380 \mathrm{~nm}$, overlapped and interfered mutually. Therefore, the separation process should be improved. Despite this issue, obviously, P25 reached the saturation of photocatalytic performance at around $90 \mathrm{~min}$ of light irradiation. Meanwhile, $\mathrm{ZnTiO}_{3}-700{ }^{\circ} \mathrm{C}$ still maintained its effective photocatalytic activity. Accordingly, $\mathrm{ZnTiO}_{3}-70{ }^{\circ} \mathrm{C}$ might be a better potential photocatalyst than $\mathrm{P} 25$. Moreover, the photocatalysts after the reaction were examined by XRD in order to check the stability of $\mathrm{ZnTiO}_{3}-700{ }^{\circ} \mathrm{C}$. We found that the main peaks of the XRD signals were the same, suggesting that the $\mathrm{ZnTiO}_{3}-700{ }^{\circ} \mathrm{C}$ photocatalyst with high-temperature calcination is stable in the photocatalytic reaction.
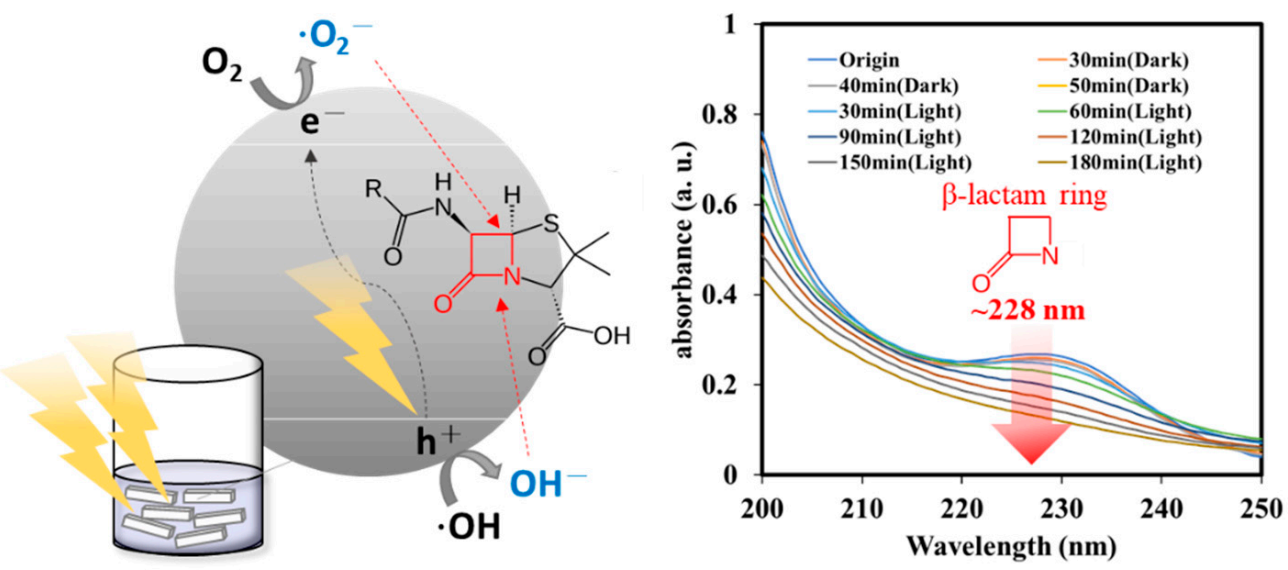

Figure 8. The possible photocatalysis mechanism for the photocatalytic degradation of AMX.

Furthermore, the photocatalytic degradation of various pollutants, including TC, $\mathrm{MB}$, and MO solutions and AMX in the presence of the $\mathrm{ZnTiO}_{3}-700{ }^{\circ} \mathrm{C}$ photocatalyst, was also performed. The concentrations of these pollutants were identified by UV-Vis at the wavelengths of $357 \mathrm{~nm}$ for TC, $664 \mathrm{~nm}$ for MB, and $464 \mathrm{~nm}$ for MO. Their initial concentrations were individually set at $10 \mathrm{ppm}$. Afterward, dark adsorption was also examined for $50 \mathrm{~min}$, followed by a $180 \mathrm{~min}$ photocatalytic reaction. Under $3 \mathrm{~h}$ of UV light irradiation, the concentration ratio decreased with time. As shown in Figure 9, the $\mathrm{ZnTiO}_{3}-700{ }^{\circ} \mathrm{C}$ photocatalyst could remove TC, MB, MO, and AMX at overall ratios of 94.8, 57.4, 42.6, and $63.8 \%$, respectively. Interestingly, $\mathrm{ZnTiO}_{3}-700{ }^{\circ} \mathrm{C}$ demonstrated a good dark adsorption capability, which might be attributed to the attractive interaction among the five polar hydroxyl groups of TC and the surficial OH groups of $\mathrm{ZnTiO}_{3}-700{ }^{\circ} \mathrm{C}$. In Figure $9 \mathrm{a}$, the TC concentration decreased up to $17 \%$ during the dark absorption in the presence of $\mathrm{ZnTiO}_{3}-700{ }^{\circ} \mathrm{C}$. After the appropriate dark adsorption, the $\mathrm{ZnTiO}_{3}-700{ }^{\circ} \mathrm{C}$ photocatalyst subsequently exhibited outstanding photocatalytic performance on TC degradation, as shown in Figure 9b. On the contrary, AMX, MB, and MO have more nonpolar branches with carbon-containing chemical structures. These are not conducive to entering the active sites on the mesoporous catalysts, which reduces the photodegradation effect. 

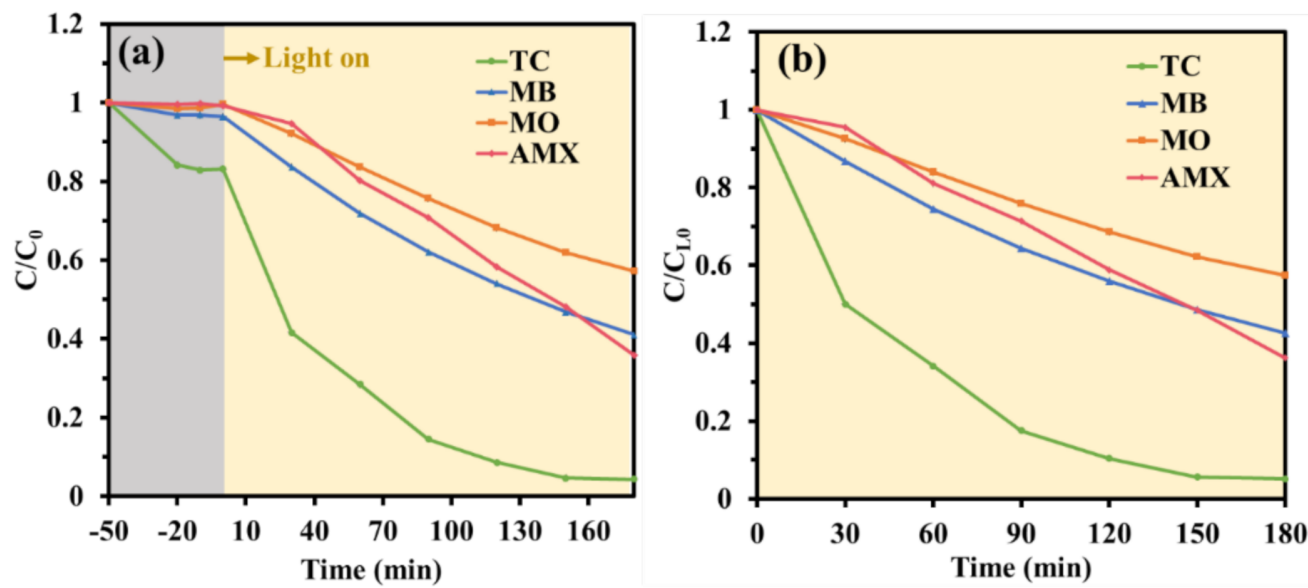

Figure 9. The changes of (a) $\mathrm{C} / \mathrm{C}_{0}$ and (b) $\mathrm{C} / \mathrm{C}_{\mathrm{L} 0}$ with the reaction time by using $\mathrm{ZnTiO}_{3}-700{ }^{\circ} \mathrm{C}$ to degrade TC, MB, MO, and AMX.

In order to compare the photocatalytic performance of various $\mathrm{ZnTiO}_{3}$ calcinated at 500-800 ${ }^{\circ} \mathrm{C}$, the first-order kinetics model [61] was adopted to analyze the effect of $\mathrm{ZnTiO}_{3}$ prepared at various calcination temperatures on the photocatalytic degradation of AMX, as shown in Figure 10a. As expected, $\mathrm{ZnTiO}_{3}-700{ }^{\circ} \mathrm{C}$ exhibited the highest first-order rate constant of $0.0049 \mathrm{~min}^{-1}$ compared to the other $\mathrm{ZnTiO}_{3}$ prepared at 500,600 , and $800{ }^{\circ} \mathrm{C}$. Furthermore, the photocatalytic degradation of $\mathrm{TC}, \mathrm{MB}$, and $\mathrm{MO}$ using $\mathrm{ZnTiO}_{3}-700{ }^{\circ} \mathrm{C}$ met the first-order kinetics model with rate constants of $0.0181,0.0048$, and 0.0031 , respectively, the detailed information of which is exposure in Figure $10 \mathrm{~b}$ and summarized in Table 3.
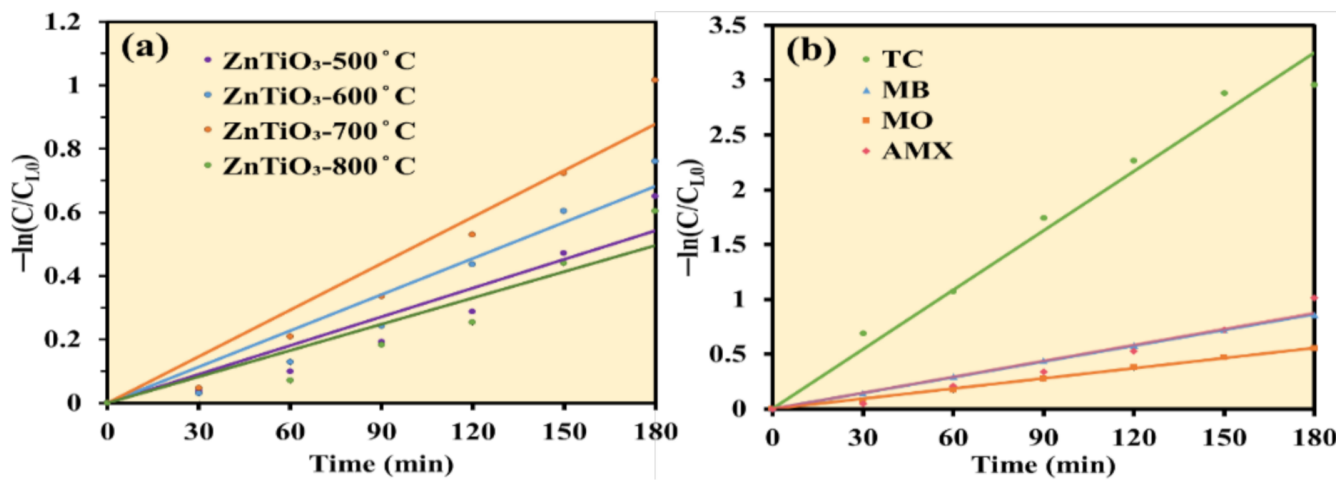

Figure 10. The photocatalytic performance based on the first-order kinetics model (a) in degrading AMX on various $\mathrm{ZnTiO}_{3}$ calcinated at $500-800^{\circ} \mathrm{C}$ and (b) in degrading TC, MB, MO, and AMX using $\mathrm{ZnTiO}_{3}-700{ }^{\circ} \mathrm{C}$.

Table 3. First-order rate constants of various $\mathrm{ZnTiO}_{3}$ for the photocatalytic degradation of various pollutants.

\begin{tabular}{cccc}
\hline Catalysts & Pollutant & $\mathbf{k}(\mathbf{m i n}-\mathbf{1})$ & $\mathbf{R}^{\mathbf{2}}$ \\
\hline $\mathrm{ZnTiO}_{3}-500{ }^{\circ} \mathrm{C}$ & $\mathrm{AMX}$ & 0.0030 & 0.9036 \\
\hline $\mathrm{ZnTiO}_{3}-600^{\circ} \mathrm{C}$ & $\mathrm{AMX}$ & 0.0038 & 0.9340 \\
\hline $\mathrm{ZnTiO}_{3}-800^{\circ} \mathrm{C}$ & $\mathrm{AMX}$ & 0.0028 & 0.8784 \\
\hline & $\mathrm{AMX}$ & 0.0049 & 0.9401 \\
\cline { 2 - 4 } $\mathrm{ZnTiO}_{3}-700{ }^{\circ} \mathrm{C}$ & $\mathrm{TC}$ & 0.0181 & 0.9784 \\
\cline { 2 - 4 } & $\mathrm{MB}$ & 0.0048 & 0.9996 \\
& $\mathrm{MO}$ & 0.0031 & 0.9979 \\
\hline
\end{tabular}




\section{Experimental}

\subsection{Materials and Reagents}

Titanium(IV) isopropoxide (TTIP, 97\%), tetracycline (TC, >98\%), amoxicillin (AMX, potency: $\geq 900 \mu \mathrm{g} / \mathrm{mg}$ ), methylene blue (MB), and methyl orange (MO) were obtained from Sigma-Aldrich (Missouri, USA). Polyvinylpyrrolidone (PVP, 100.0\%) was purchased from Acros Organics. Ethylene glycol (MEG, >99\%) was received from SHOWA. Ethanol (99.9\%) and aqua ammonia $\left(\mathrm{NH}_{4} \mathrm{OH}, 28.0 \sim 30.0 \%\right)$ were obtained from J.T.Baker. Zinc acetate dihydrate (ACS, 98.0-101.0\%) was obtained from Alfa Aesar.

\subsection{Synthesis of $\mathrm{ZnTiO}_{3}$}

The $\mathrm{ZnTiO}_{3}$ photocatalysts were fabricated by the sol-gel process by adding a PVP template. First, $1.2 \mathrm{~g}$ of zinc acetate dihydrate, as the precursor of $\mathrm{ZnTiO}_{3}$, providing the $\mathrm{Zn}$ source, was dissolved in $100 \mathrm{~mL}$ of MEG to obtain Solution A. Similarly, $1.65 \mathrm{~mL}$ of TTIP served as the Ti source for $\mathrm{ZnTiO}_{3}$ and was mixed into $100 \mathrm{~mL}$ of MEG to obtain Solution B. Solution C comprised 5 or $7 \mathrm{~g}$ PVP as the template, 750,1500 , or $3000 \mu \mathrm{L} \mathrm{NH} \mathrm{NH}_{4} \mathrm{OH}$ as the alkaline source, and $120 \mathrm{~mL}$ MEG as the solvent. Next, Solution B was added gently into Solution A under continuous stirring, to obtain Solution D. Then, Solution D was mixed by stirring with Solution $\mathrm{C}$ in the constant-temperature reactor, which controlled the temperature at $50{ }^{\circ} \mathrm{C}$ using a water bath. The mixtures were continuously agitated at a fixed temperature of $50^{\circ} \mathrm{C}$ for $20 \mathrm{~h}$. Afterward, a milky white solution was formed according to the chemical reaction as follows:

$\mathrm{Zn}\left(\mathrm{CH}_{3} \mathrm{COO}\right)_{2}+2 \mathrm{NH}_{3} \cdot \mathrm{H}_{2} \mathrm{O}+3 \mathrm{H}_{2} \mathrm{O}+\mathrm{Ti}\left(\mathrm{OC}_{3} \mathrm{H}_{7}\right)_{4} \rightarrow \mathrm{Zn}(\mathrm{OH})_{2} \downarrow+\mathrm{TiO}(\mathrm{OH})_{2} \downarrow+2 \mathrm{NH}_{4} \mathrm{CH}_{3} \mathrm{COO}+4 \mathrm{C}_{3} \mathrm{H}_{7} \mathrm{OH}$

After this, the milky white solution was centrifuged at $3200 \times g$ for $30 \mathrm{~min}$, followed by removing the supernatant and obtaining the sediment. The sediment was washed out from the bottom of the centrifuge tube with ethanol. The sediment and ethanol solution was poured into a flat-bottom flask and then concentrated at $60^{\circ} \mathrm{C}$ in a vertical rotary vacuum concentrator. When there was no more solvent gathered in the collection bottle of the concentrator, $160 \mathrm{~mL}$ of ethanol was further added into the flask and well mixed with the precipitation to gain a thick white liquid. The thick liquid was subsequently placed in a crucible for vacuum drying at $60{ }^{\circ} \mathrm{C}$ for $10 \mathrm{~h}$. The dried samples were then calcinated at the designed temperature of $500,600,700$, and $800{ }^{\circ} \mathrm{C}$ for $3 \mathrm{~h}$. Ultimately, the $\mathrm{ZnTiO}_{3}$ photocatalysts were obtained by grinding these flaky and calcinated powders.

\subsection{Characterizations}

The crystal phase of the $\mathrm{ZnTiO}_{3}$ photocatalysts was elucidated by the X-ray diffraction patterns (XRD) using D8 ADVANCE (Bruker, Germany). The wavelength of the $\mathrm{CuK} \alpha$ target was $0.15406 \mathrm{~nm}$, excited by $40 \mathrm{kV}$ of working voltage. The scan rate was $4^{\circ} / \mathrm{min}$, and the range of the scanning angle was from $20^{\circ}$ to $80^{\circ}$. The infrared absorption pattern was examined using Spectrum One (Perkin Elmer, USA, Waltham, MA, USA) as the Fourier transform infrared spectroscope (FTIR). The morphology and composition of the photocatalysts were observed by employing JSM-6701F (JEOL, Tokyo, Japan) as the scanning electron microscope (SEM), equipped with INCA X-act (Oxford Instruments, Oxford, U.K.) as the energy dispersion spectroscope (EDS). The $\mathrm{N}_{2}$ adsorption-desorption isotherm curves of the photocatalysts at $77 \mathrm{~K}$ were inspected to reveal the property of the specific surface area using a physisorption analyzer (ASAP 2020 PLUS, USA) and Brunauer-Emmett-Teller (BET) method. The diffuse reflectance UV-Vis spectra at $200 \sim 800 \mathrm{~nm}$ were measured by applying a UV-Vis spectrophotometer (V-670, JASCO, Pfungstadt, Germany). The thermogravimetric analysis (TGA) and differential thermal analysis (DTA) were also performed using the simultaneous thermogravimetric analyzer (SDT 2960, TA Instruments, USA). 


\subsection{Photocatalytic AMX Degradation}

The removal of AMX was achieved with two processes, dark adsorption and photocatalytic degradation. Firstly, $50 \mathrm{mg}$ of the $\mathrm{ZnTiO}_{3}$ photocatalysts was suspended with continuous stirring in a $100 \mathrm{~mL}$ AMX solution, with an initial concentration of $10 \mathrm{ppm}\left(\mathrm{C}_{0}\right)$. Then, the dark adsorption process of AMX was carried out on the $\mathrm{ZnTiO}_{3}$ photocatalysts covered by a black box. During the dark adsorption, $3 \mathrm{~mL}$ AMX solution was taken out at the 30th, 40th, and 50th minute for sampling. After that, the adsorption and desorption were regarded as reaching an equilibrium, and the concentration $\left(\mathrm{C}_{\mathrm{L} 0}\right)$ was noted. Subsequently, UV LEDs $(8 \mathrm{~W} \times 4)$ within a wavelength range of $280 \sim 320 \mathrm{~nm}$ (G8T5E, Sankyo-Denki, Tokyo, Japan) were turned on to irradiate the AMX solution to facilitate the photocatalytic degradation. After $30 \mathrm{~min}$ of irradiation, the $3 \mathrm{~mL}$ AMX solution was sampled to inspect the concentration (C) at the 30th, 60th, 90th, 120th, 150th, and 180th minute. Then, each $3 \mathrm{~mL}$ sample of the AMX solution was centrifuged at $3200 \times g$ for $15 \mathrm{~min}$ to remove the $\mathrm{ZnTiO}_{3}$ sediment. The supernatant solution was detected by employing a UV-Vis spectroscope to identify the concentration of AMX, which showed a characterized absorption peak at $\sim 228 \mathrm{~nm}$ in the spectrum. This wavelength is the absorption of the $\beta$ lactam ring of the pharmacophore of AMX [62], and the $\beta$-lactam ring would be destroyed by the photocatalytic reaction.

\section{Conclusions}

In this study, $\mathrm{ZnTiO}_{3}$ photocatalysts were successfully fabricated using the sol-gel process. The influence of the calcination temperature, $\mathrm{NH}_{4} \mathrm{OH}$ addition, and PVP addition during the synthesis on their characteristics was discussed. Furthermore, the photocatalytic performances of the $\mathrm{ZnTiO}_{3}$ photocatalysts in decomposing emerging pollutants, such as AMX, TC, MB, and MO, were also examined. The results showed that the different calcination temperatures significantly affected the photocatalytic performance in the degradation of the AMX. Under a low calcination temperature of $500^{\circ} \mathrm{C}$, the resulting photocatalyst showed a poor crystalline phase. As the calcination temperature increased to $600{ }^{\circ} \mathrm{C}$, an obvious cubic $\mathrm{ZnTiO}_{3}$ phase appeared. As the calcination temperature reached $700{ }^{\circ} \mathrm{C}$, the photocatalysts had a sharp cubic $\mathrm{ZnTiO}_{3}$ phase and showed an excellent photocatalytic degradation of the AMX. However, some hexagonal $\mathrm{ZnTiO}_{3}$ appeared while calcinating the samples at $800{ }^{\circ} \mathrm{C}$, leading to a smaller specific surface area and less satisfactory photocatalytic performance. Based on setting the calcination temperature at $700{ }^{\circ} \mathrm{C}$, no matter the amount of $\mathrm{NH}_{4} \mathrm{OH}$ or PVP added during the synthesis, the effect on the pore properties and crystal phase was not significant. This indicated that the photocatalytic performance was related to the pore properties and crystal phase of the cubic $\mathrm{ZnTiO}_{3}$.

Moreover, the synthesized $\mathrm{ZnTiO}_{3}-700{ }^{\circ} \mathrm{C}$ met the type IV isotherm and revealed the mesoporous property with the pore size distribution from $2 \sim 50 \mathrm{~nm}$. Accordingly, the $\mathrm{ZnTiO}_{3}-700{ }^{\circ} \mathrm{C}$ photocatalyst was employed to remove different organic pollutants, including $\mathrm{TC}, \mathrm{MB}$, and $\mathrm{MO}$, under UVB light irradiation. Among these pollutants, the degradation effect of TC in the presence of $\mathrm{ZnTiO}_{3}-700{ }^{\circ} \mathrm{C}$ could reach $94.8 \%$. It was speculated that there are multipolar $\mathrm{OH}$ groups on $\mathrm{TC}$, which would attract the $\mathrm{OH}$ groups on the surface of the $\mathrm{ZnTiO}_{3}-700{ }^{\circ} \mathrm{C}$ photocatalyst. Subsequently, it is easier for TC to be adsorbed into the pores of the $\mathrm{ZnTiO}_{3}-700{ }^{\circ} \mathrm{C}$ photocatalyst, followed by the contact of the active sites with the photocatalysts. To sum up, the calcination temperature was the primary factor influencing the pore structure and crystal phase of the $\mathrm{ZnTiO}_{3}-700{ }^{\circ} \mathrm{C}$ photocatalyst, which showed great potential for the photocatalytic degradation of AMX, $\mathrm{TC}, \mathrm{MO}$, and $\mathrm{MB}$ under the irradiation of low-intensity UV light.

Supplementary Materials: The following are available online at https:/ /www.mdpi.com/article/10 .3390 / catal11070854/s1, Figure S1: XRD patterns of $\mathrm{ZnTiO}_{3}$ photocatalysts (synthesized by adding $5 \mathrm{~g}$ PVP) under the calcination temperature of $700{ }^{\circ} \mathrm{C}$ with various amounts of $\mathrm{NH}_{4} \mathrm{OH}$ addition (750, 1500, and $3000 \mu \mathrm{L}$ ); Figure S2. The XRD patterns of $\mathrm{ZnTiO}_{3}$ photocatalysts prepared by adding $3 \mathrm{~g}$ and $5 \mathrm{~g}$ PVP under the calcination temperature of $700{ }^{\circ} \mathrm{C}$ with $\mathrm{NH}_{4} \mathrm{OH}$ addition of $1500 \mu \mathrm{L}$; 
Figure S3. FTIR spectra of various $\mathrm{ZnTiO}_{3}$ prepared by various conditions; Figure S4. (a)-(d) and (d)-(f) the SEM images at the magnification of 10,000 $\times$ and 30,000 $\times$ of $\mathrm{ZnTiO}_{3}-\mathrm{N} 750, \mathrm{ZnTiO}_{3}-\mathrm{N}_{1500 \text {, }}$ and $\mathrm{ZnTiO}_{3}-3000$; Figure S5. the SEM images at the magnification of $30,000 \times$ of (a) $\mathrm{ZnTiO}_{3}-\mathrm{P} 3$ and (b) $\mathrm{ZnTiO}_{3}-\mathrm{P} 5$; Figure S6. N2 adsorption-desorption isotherms of $\mathrm{ZnTiO}_{3}$ prepared various $\mathrm{NH}_{4} \mathrm{OH}$ and PVP modification; Figure S7. UV-Vis result of $\mathrm{ZnTiO}_{3}$ prepared by various amounts of $\mathrm{NH}_{4} \mathrm{OH}$ and PVP modification; Figure S8. The changes of $C / C_{L 0}$ with reaction time (a) for various amounts of $\mathrm{NH}_{4} \mathrm{OH}$ addition and (b) for various amounts of PVP addition; Figure S9. The changes of $\mathrm{C} / \mathrm{C}_{0}$ with reaction time by using $\mathrm{P} 25$ and $\mathrm{ZnTiO}_{3}-700{ }^{\circ} \mathrm{C}$; Table S1. the comparison of activities over different photocatalysts to degrade AMX.

Author Contributions: Conceptualization, C.-W.H.; Formal analysis, C.-P.W.; Investigation, C.-P.W. and P.-C.C.; Methodology, C.-P.W. and P.-C.C.; Writing - original draft, C.-W.H.; Writing - review \& editing, W.-Y.C., K.-Y.A.L., S.G., C.-W.H. and V.-H.N. All authors have read and agreed to the published version of the manuscript.

Funding: This research was funded by the Ministry of Science and Technology (MOST) of Taiwan, grant number MOST 109-2221-E-992-035 and 110-2221-E-992-030-MY3.

Data Availability Statement: Not applicable.

Acknowledgments: We thank the Ministry of Science and Technology (MOST) of Taiwan under MOST 109-2221-E-992-035 and 110-2221-E-992-030-MY3.

Conflicts of Interest: The authors declare no conflict of interest.

\section{References}

1. Sanganyado, E.; Gwenzi, W. Antibiotic resistance in drinking water systems: Occurrence, removal, and human health risks. Sci. Total. Environ. 2019, 669, 785-797. [CrossRef]

2. Vranakis, I.; Goniotakis, I.; Psaroulaki, A.; Sandalakis, V.; Tselentis, Y.; Gevaert, K.; Tsiotis, G. Proteome studies of bacterial antibiotic resistance mechanisms. J. Proteom. 2014, 97, 88-99. [CrossRef] [PubMed]

3. Verma, M.; Haritash, A.K. Degradation of amoxicillin by fenton and fenton-integrated hybrid oxidation processes. J. Environ. Chem. Eng. 2019, 7, 102886. [CrossRef]

4. Chaturvedi, P.; Shukla, P.; Giri, B.S.; Chowdhary, P.; Chandra, R.; Gupta, P.; Pandey, A. Prevalence and hazardous impact of pharmaceutical and personal care products and antibiotics in environment: A review on emerging contaminants. Environ. Res. 2021, 194, 110664. [CrossRef] [PubMed]

5. Kümmerer, K.; Henninger, A. Promoting resistance by the emission of antibiotics from hospitals and households into effluent. Clin. Microbiol. Infect. 2003, 9, 1203-1214. [CrossRef]

6. Gozlan, I.; Rotstein, A.; Avisar, D. Amoxicillin-degradation products formed under controlled environmental conditions: Identification and determination in the aquatic environment. Chemosphere 2013, 91, 985-992. [CrossRef] [PubMed]

7. Montanha, M.C.; dos Santos Magon, T.F.; de Souza Alcantara, C.; Simões, C.F.; Silva, S.R.B.; Kuroda, C.M.; Yamada, S.S.; de Oliveira, L.E.S.; Nasser, D.; Junior, N.N. Reduced bioavailability of oral amoxicillin tablets compared to suspensions in roux-en-y gastric bypass bariatric subjects. Br. J. Clin. Pharmacol. 2019, 85, 2118-2125. [CrossRef] [PubMed]

8. Jung, C.; Son, A.; Her, N.; Zoh, K.-D.; Cho, J.; Yoon, Y. Removal of endocrine disrupting compounds, pharmaceuticals, and personal care products in water using carbon nanotubes: A review. J. Ind. Eng. Chem. 2015, 27, 1-11. [CrossRef]

9. Chu, K.H.; Al-Hamadani, Y.A.J.; Park, C.M.; Lee, G.; Jang, M.; Jang, A.; Her, N.; Son, A.; Yoon, Y. Ultrasonic treatment of endocrine disrupting compounds, pharmaceuticals, and personal care products in water: A review. Chem. Eng. J. 2017, 327, 629-647. [CrossRef]

10. Singh, P.; Raizada, P.; Pathania, D.; Sharma, G.; Sharma, P. Microwave induced koh activation of guava peel carbon as an adsorbent for congo red dye removal from aqueous phase. Indian J. Chem. Technol. 2013, 20, 305-311.

11. Pare, B.; Singh, P.; Jonnalgadda, S. Degradation and mineralization of victoria blue $b$ dye in a slurry photoreactor using advanced oxidation process. J. Sci. Ind. Res. 2009, 68, 724-729.

12. Wang, J.; Zhuan, R. Degradation of antibiotics by advanced oxidation processes: An overview. Sci. Total. Environ. 2020, 701, 135023. [CrossRef]

13. Souza, F.S.; da Silva, V.V.; Rosin, C.K.; Hainzenreder, L.; Arenzon, A.; Féris, L.A. Comparison of different advanced oxidation processes for the removal of amoxicillin in aqueous solution. Environ. Technol. 2018, 39, 549-557. [CrossRef]

14. Huang, C.-W.; Sin, W.-C.; Nguyen, V.-H.; Wu, Y.-C.; Chen, W.-Y.; Chien, A.C. Solvothermal synthesis of mesoporous tio2 using sodium dodecyl sulfate for photocatalytic degradation of methylene blue. Top. Catal. 2020, 63, 1121-1130. [CrossRef]

15. Kumar, A.; Rana, A.; Sharma, G.; Naushad, M.; Dhiman, P.; Kumari, A.; Stadler, F.J. Recent advances in nano-fenton catalytic degradation of emerging pharmaceutical contaminants. J. Mol. Liq. 2019, 290, 111177. [CrossRef]

16. Liang, S.-X.; Wang, X.; Zhang, W.; Liu, Y.-J.; Wang, W.; Zhang, L.-C. Selective laser melting manufactured porous fe-based metallic glass matrix composite with remarkable catalytic activity and reusability. Appl. Mater. Today 2020, 19, 100543. [CrossRef] 
17. Wang, Q.; Chen, M.; Lin, P.; Cui, Z.; Chu, C.; Shen, B. Investigation of fepc amorphous alloys with self-renewing behaviour for highly efficient decolorization of methylene blue. J. Mater. Chem. A 2018, 6, 10686-10699. [CrossRef]

18. Jia, Z.; Kang, J.; Zhang, W.; Wang, W.; Yang, C.; Sun, H.; Habibi, D.; Zhang, L. Surface aging behaviour of fe-based amorphous alloys as catalysts during heterogeneous photo fenton-like process for water treatment. Appl. Catal. B Environ. 2017, $204,537-547$. [CrossRef]

19. Sopaj, F.; Rodrigo, M.A.; Oturan, N.; Podvorica, F.I.; Pinson, J.; Oturan, M.A. Influence of the anode materials on the electrochemical oxidation efficiency. Application to oxidative degradation of the pharmaceutical amoxicillin. Chem. Eng. J. 2015, 262, 286-294. [CrossRef]

20. Changotra, R.; Rajput, H.; Guin, J.P.; Dhir, A. Comparative assessment of application of ionizing radiations in degradation of amoxicillin trihydrate (amt) in aqueous solutions. Chem. Eng. J. 2020, 421, 127847. [CrossRef]

21. Huang, C.W.; Wu, M.C. Photocatalytic degradation of methylene blue by uv-assistant tio2 and natural sericite composites. J. Chem. Technol. Biotechnol. 2020, 95, 2715-2722.

22. Thi, L.-A.P.; Panchangam, S.C.; Do, H.-T.; Nguyen, V.-H. Chapter 17-Prospects and Challenges of Photocatalysis for Degradation and Mineralization of Antiviral Drugs. In Nanostructured Photocatalysts; Nguyen, V.-H., Vo, D.-V.N., Nanda, S., Eds.; Elsevier: Amsterdam, The Netherlands, 2021; pp. 489-517.

23. Nguyen, V.-H.; Tran, Q.B.; Nguyen, X.C.; Hai, L.T.; Ho, T.T.T.; Shokouhimehr, M.; Vo, D.-V.N.; Lam, S.S.; Nguyen, H.P.; Hoang, C.T.; et al. Submerged photocatalytic membrane reactor with suspended and immobilized n-doped tio2 under visible irradiation for diclofenac removal from wastewater. Process. Saf. Environ. Prot. 2020, 142, 229-237. [CrossRef]

24. Nguyen, V.-H.; Phan Thi, L.-A.; Chandana, P.S.; Do, H.-T.; Pham, T.-H.; Lee, T.; Nguyen, T.D.; Le Phuoc, C.; Huong, P.T. The degradation of paraben preservatives: Recent progress and sustainable approaches toward photocatalysis. Chemosphere 2021, 276, 130163. [CrossRef]

25. Nguyen, V.-H.; Smith, S.M.; Wantala, K.; Kajitvichyanukul, P. Photocatalytic remediation of persistent organic pollutants (pops): A review. Arab. J. Chem. 2020, 13, 8309-8337. [CrossRef]

26. Lu, K.-T.; Nguyen, V.-H.; Yu, Y.-H.; Yu, C.-C.; Wu, J.C.S.; Chang, L.-M.; Lin, A.Y.-C. An internal-illuminated monolith photoreactor towards efficient photocatalytic degradation of ppb-level isopropyl alcohol. Chem. Eng. J. 2016, 296, 11-18. [CrossRef]

27. Nguyen, V.-H.; Phan Thi, L.-A.; Van Le, Q.; Singh, P.; Raizada, P.; Kajitvichyanukul, P. Tailored photocatalysts and revealed reaction pathways for photodegradation of polycyclic aromatic hydrocarbons (pahs) in water, soil and other sources. Chemosphere 2020, 260, 127529. [CrossRef]

28. Do, H.-T.; Phan Thi, L.-A.; Dao Nguyen, N.H.; Huang, C.-W.; Le, Q.V.; Nguyen, V.-H. Tailoring photocatalysts and elucidating mechanisms of photocatalytic degradation of perfluorocarboxylic acids (pfcas) in water: A comparative overview. J. Chem. Technol. Biotechnol. 2020, 95, 2569-2578. [CrossRef]

29. Patial, S.; Raizada, P.; Hasija, V.; Singh, P.; Thakur, V.K.; Nguyen, V.H. Recent advances in photocatalytic multivariate metal organic frameworks-based nanostructures toward renewable energy and the removal of environmental pollutants. Mater. Today Energy 2021, 19, 100589. [CrossRef]

30. Dutta, V.; Sharma, S.; Raizada, P.; Khan, A.A.P.; Asiri, A.M.; Nadda, A.; Singh, P.; Van Le, Q.; Huang, C.-W.; Nguyen, D.L.T.; et al. Recent advances and emerging trends in (bio)2co3 based photocatalysts for environmental remediation: A review. Surf. Interfaces 2021, 25, 101273. [CrossRef]

31. Dimitrakopoulou, D.; Rethemiotaki, I.; Frontistis, Z.; Xekoukoulotakis, N.P.; Venieri, D.; Mantzavinos, D. Degradation, mineralization and antibiotic inactivation of amoxicillin by uv-a/tio2 photocatalysis. J. Environ. Manag. 2012, 98, 168-174. [CrossRef] [PubMed]

32. Bergamonti, L.; Bergonzi, C.; Graiff, C.; Lottici, P.P.; Bettini, R.; Elviri, L. 3d printed chitosan scaffolds: A new tio2 support for the photocatalytic degradation of amoxicillin in water. Water Res. 2019, 163, 114841. [CrossRef]

33. Ramandi, S.; Entezari, M.H.; Ghows, N. Sono-synthesis of novel magnetic nanocomposite (ba- $\alpha$-bi2o3- $\gamma$-fe2o3) for the solar mineralization of amoxicillin in an aqueous solution. Phys. Chem. Res. 2017, 5, 253-268.

34. Hsiao, C.-Y.; Hung, C.; Kwon, E.; Huang, C.-W.; Huang, C.-F.; Lin, K.-Y.A. Electrospun nanoscale iron oxide-decorated carbon fiber as an efficient heterogeneous catalyst for activating percarbonate to degrade azorubin s in water. J. Water Process. Eng. 2020, 40, 101838. [CrossRef]

35. Nguyen, T.D.; Nguyen, V.-H.; Nanda, S.; Vo, D.-V.N.; Nguyen, V.H.; Van Tran, T.; Nong, L.X.; Nguyen, T.T.; Bach, L.-G.; Abdullah, B.; et al. Bivo4 photocatalysis design and applications to oxygen production and degradation of organic compounds: A review. Environ. Chem. Lett. 2020, 18, 1779-1801. [CrossRef]

36. Elmolla, E.S.; Chaudhuri, M. Degradation of amoxicillin, ampicillin and cloxacillin antibiotics in aqueous solution by the uv/zno photocatalytic process. J. Hazard. Mater. 2010, 173, 445-449. [CrossRef] [PubMed]

37. Majumder, S.; Chatterjee, S.; Basnet, P.; Mukherjee, J. Zno based nanomaterials for photocatalytic degradation of aqueous pharmaceutical waste solutions-a contemporary review. Environ. Nanotechnol. Monit. Manag. 2020, 14, 100386. [CrossRef]

38. Leong, K.H.; Gan, B.L.; Ibrahim, S.; Saravanan, P. Synthesis of surface plasmon resonance (spr) triggered ag/tio2 photocatalyst for degradation of endocrine disturbing compounds. Appl. Surf. Sci. 2014, 319, 128-135. [CrossRef]

39. Kanakaraju, D.; Kockler, J.; Motti, C.A.; Glass, B.D.; Oelgemöller, M. Titanium dioxide/zeolite integrated photocatalytic adsorbents for the degradation of amoxicillin. Appl. Catal. B Environ. 2015, 166-167, 45-55. [CrossRef] 
40. Belaissa, Y.; Nibou, D.; Assadi, A.A.; Bellal, B.; Trari, M. A new hetero-junction p-cuo/n-zno for the removal of amoxicillin by photocatalysis under solar irradiation. J. Taiwan Inst. Chem. Eng. 2016, 68, 254-265. [CrossRef]

41. Yang, C.; You, X.; Cheng, J.; Zheng, H.; Chen, Y. A novel visible-light-driven in-based mof/graphene oxide composite photocatalyst with enhanced photocatalytic activity toward the degradation of amoxicillin. Appl. Catal. B Environ. 2017, 200, 673-680. [CrossRef]

42. Dou, M.; Wang, J.; Gao, B.; Xu, C.; Yang, F. Photocatalytic difference of amoxicillin and cefotaxime under visible light by mesoporous g-c3n4: Mechanism, degradation pathway and dft calculation. Chem. Eng. J. 2019, 123134. [CrossRef]

43. Mirzaei, A.; Chen, Z.; Haghighat, F.; Yerushalmi, L. Magnetic fluorinated mesoporous g-c3n4 for photocatalytic degradation of amoxicillin: Transformation mechanism and toxicity assessment. Appl. Catal. B Environ. 2019, 242, 337-348. [CrossRef]

44. Haddadou, N.; Bensemma, N.; Rekhila, G.; Trari, M.; Taibi, K. Photoelectrochemical investigations in lead-free ba (ti0.950sc0.025nb0.025)o3 ferroelectric ceramics. Application to amoxicillin photodegradation. J. Photochem. Photobiol. A Chem. 2018, 358, 294-299. [CrossRef]

45. Kong, J.-Z.; Li, A.-D.; Zhai, H.-F.; Li, H.; Yan, Q.-Y.; Ma, J.; Wu, D. Preparation, characterization and photocatalytic properties of zntio3 powders. J. Hazard. Mater. 2009, 171, 918-923. [CrossRef]

46. Ozturk, B.; Soylu, G.S.P. Promoting role of transition metal oxide on zntio3-tio2 nanocomposites for the photocatalytic activity under solar light irradiation. Ceram. Int. 2016, 42, 11184-11192. [CrossRef]

47. Cai, Z.; Li, J.; Wang, Y. Fabrication of zinc titanate nanofibers by electrospinning technique. J. Alloys Compd. 2010, 489, 167-169. [CrossRef]

48. Hou, L.; Hou, Y.-D.; Zhu, M.-K.; Tang, J.; Liu, J.-B.; Wang, H.; Yan, H. Formation and transformation of zntio3 prepared by sol-gel process. Mater. Lett. 2005, 59, 197-200. [CrossRef]

49. Lokesh, B.; Kaleemulla, S.; Rao, N.M. Synthesis and characterization of zinc titanates by solid state reaction. Int. J. Chem. Tech. Res. 2014, 6, 1929-1932.

50. Koczkur, K.M.; Mourdikoudis, S.; Polavarapu, L.; Skrabalak, S.E. Polyvinylpyrrolidone (pvp) in nanoparticle synthesis. Dalton Trans. 2015, 44, 17883-17905. [CrossRef]

51. Tahay, P.; Khani, Y.; Jabari, M.; Bahadoran, F.; Safari, N.; Zamanian, A. Synthesis of cubic and hexagonal zntio3 as catalyst support in steam reforming of methanol: Study of physical and chemical properties of copper catalysts on the h2 and co selectivity and coke formation. Int. J. Hydrogen Energy 2020, 45, 9484-9495. [CrossRef]

52. Li, J.; Cui, H.; Mu, D.; Liu, Y.; Guan, T.; Xia, Z.; Jiang, L.; Zuo, J.; Tan, C.; You, H. Synthesis and characterization of rgo decorated cubic zntio 3 rods for solar light-induced photodegradation of rhodamine b. New J. Chem. 2019, 43, 3374-3382. [CrossRef]

53. Chi, Y.; Yuan, Q.; Hou, S.; Zhao, Z. Synthesis and characterization of mesoporous zntio3 rods via a polyvinylpyrrolidone assisted sol-gel method. Ceram. Int. 2016, 42, 5094-5099. [CrossRef]

54. Chang, Y.-S.; Chang, Y.-H.; Chen, I.-G.; Chen, G.-J.; Chai, Y.-L. Synthesis and characterization of zinc titanate nano-crystal powders by sol-gel technique. J. Cryst. Growth 2002, 243, 319-326. [CrossRef]

55. Luo, Z.; Li, H.; Xia, J.; Zhu, W.; Guo, J.; Zhang, B. Microwave-assisted synthesis of barium tungstate nanosheets and nanobelts by using polymer pvp micelle as templates. Mater. Lett. 2007, 61, 1845-1848. [CrossRef]

56. Kuchi, C.; Harish, G.S.; Reddy, P.S. Effect of polymer concentration, needle diameter and annealing temperature on tio2-pvp composite nanofibers synthesized by electrospinning technique. Ceram. Int. 2018, 44, 5266-5272. [CrossRef]

57. Al-Hajji, L.A.; Ismail, A.A.; Al-Hazza, A.; Ahmed, S.A.; Alsaidi, M.; Almutawa, F.; Bumajdad, A. Impact of calcination of hydrothermally synthesized tio2 nanowires on their photocatalytic efficiency. J. Mol. Struct. 2020, 1200, 127153. [CrossRef]

58. Yurdakal, S.; Garlisi, C.; Özcan, L.; Bellardita, M.; Palmisano, G. Chapter 4-(Photo)catalyst Characterization Techniques: Adsorption Isotherms and Bet, Sem, Ftir, Uv-Vis, Photoluminescence, and Electrochemical Characterizations. In Heterogeneous Photocatalysis; Marcì, G., Palmisano, L., Eds.; Elsevier: Amsterdam, The Netherlands, 2019; pp. 87-152.

59. Pal, N.; Paul, M.; Bhaumik, A. New mesoporous perovskite zntio3 and its excellent catalytic activity in liquid phase organic transformations. Appl. Catal. A Gen. 2011, 393, 153-160. [CrossRef]

60. Murphy, A.J.S.E.M.; Cells, S. Band-gap determination from diffuse reflectance measurements of semiconductor films, and application to photoelectrochemical water-splitting. Sol. Energy Mater. Sol. Cells 2007, 91, 1326-1337. [CrossRef]

61. Le, M.-V.; Vo, N.-Q.-D.; Le, Q.-C.; Tran, V.A.; Phan, T.; Huang, C.-W.; Nguyen, V.-H. Manipulating the structure and characterization of sr1- xlaxtio3 nanocubes toward the photodegradation of 2-naphthol under artificial solar light. Catalysts 2021, 11, 564. [CrossRef]

62. Aksu Demirezen, D.; Yıldız, Y.Ş.; Demirezen Yılmaz, D. Amoxicillin degradation using green synthesized iron oxide nanoparticles: Kinetics and mechanism analysis. Environ. Nanotechnol. Monit. Manag. 2019, 11, 100219. [CrossRef] 